Article

\title{
Estimating Energy- and Eco-Balances for Continuous Bio-Ethanol Production Using a Blenke Cascade System
}

\author{
Jean Nepomuscene Ntihuga ${ }^{1,2, *}$, Thomas Senn ${ }^{1}$, Peter Gschwind ${ }^{2}$, Reinhard Kohlus ${ }^{2}$
}

1 Department of Fermentation Technology, Institute of Food Science and Biotechnology, Hohenheim Universität, Garbenstrasse 23, Stuttgart 70599, Germany; E-Mail: thomas.senn@uni-hohenheim.de Department of Food Process Engineering, Institute of Food Science and Biotechnology, Hohenheim Universität, Garbenstrasse 25, Stuttgart 70599, Germany;

E-Mails: peter.gschwind@uni-hohenheim.de (P.G.); r.kohlus@uni-hohenheim.de (R.K.)

* Author to whom correspondence should be addressed; E-Mail address: nepo@uni-hohenheim.de; Tel.:+49-711-4592-3038; Fax: +49-711-4592-4168.

Received: 29 January 2013; in revised form: 29 March 2013 / Accepted: 29 March 2013 / Published: 11 April 2013

\begin{abstract}
Energy and environmental effects of wheat-based fuel, produced continuously by a Blenke cascade system, were assessed. Two scenarios: (1) no-co-products utilization scenario; and (2) co-products utilization scenario, were compared. A Life Cycle Assessment (LCA) model was used for analysis. The scope covered a cradle-to-gate inventory. The results from energy analysis showed, that wheat-based ethanol has a positive average net energy value $(\mathrm{NEV}), \mathrm{NEV}=3.35 \mathrm{MJ} / \mathrm{kg}$ ethanol with an average net energy ratio (NER), $\mathrm{NER}=1.14 \mathrm{MJ} / \mathrm{MJ}$ fossils for scenario 1 , while for scenario $2, \mathrm{NEV}=20 \mathrm{MJ} / \mathrm{kg}$ ethanol with NER $=3.94 \mathrm{MJ} / \mathrm{MJ}$ fossils. The environmental performance analysis indicated that in scenario 1, the strongest contribution to environmental impacts was from the ethanol conversion stage; whereas in scenario 2 , it was from wheat production stage. The use of a continuous fermentation system based on Blenke cascade is a promising technology that increases wheat based bio-ethanol's energy benefits. In addition, the calculated parameters show the potential to significantly reduce emissions level.
\end{abstract}

Keywords: bio-ethanol; Blenke cascade system; life-cycle assessment; wheat; scenarios 


\section{Introduction}

The perspective of oil depletion, the concerns of energy security and global warming are the main drivers of biofuels promotion by public authorities in industrialized countries [1,2]. The development of reliable, renewable energy systems is urgently required and is being encouraged by ambitious energy policies such as the European Union's target to attain a 20\% share of its energy consumption from renewable resources by 2020 [3]. Research on bio-ethanol production using second-generation biomass, such as cellulosic and seaweed biomass, or third generation biomass, such as algae, is undoubtedly necessary. However, it is also important to study economical bio-ethanol production systems from sugary and starchy substrates, which have become the main feedstock for bio-ethanol production [4].

The concerns about energy balances are related to both the life-cycle energy efficiency of biofuels and the savings of non-renewable energy between biofuels and fossil fuels. The latter aspect is relevant with respect to the substitution efficiency of biofuels. Therefore, less costly and more productive techniques for producing ethanol are required. In response, we had earlier proposed an energy system, where bio-ethanol was produced by continuous fermentation using a Blenke cascade system [5]. Having shown the feasibility of this technology, an evaluation of these energy systems from a comprehensive environmental approach was conducted. Life Cycle Assessment (LCA) has proven to be a valuable methodology for the evaluation of the environmental impacts of a product or process over its whole life cycle. Thus it facilitates the decision making process towards environmental sustainability [6,7]. LCA has been used to evaluate a wide range of bioenergy systems and compare them with conventional fossil energy systems. Examples include first and second generation bio-ethanol production [8-12], biodiesel production [13-16], district heat generation from biomass [17] and electricity generation [18-20].

In any energy system, it is possible, that the co-products may be used in efficient ways to make the system self-sufficient in electrical and thermal energies demands. In the present study, we aimed to compare the energy efficiency and the environmental effects of the Blenke cascade system (small-scale plant) used for conversion of wheat grain into bio-ethanol in a no-co-products utilization scenario (scenario 1) and a co-products utilization scenario (scenario 2) using LCA model.

\section{Materials and Methods}

The comparison of the two scenarios was based on life cycle assessment modelling covering cradle-to-gate inventory. The analyses used the "Ganzheitliche Bilanzierung', (abbreviation "GaBi', English: Holistic Balancing,) software including the "Lean database" (March 2006 version) by PE International $\mathrm{GmbH}$ [21]. The history of life cycle engineering, LCA and the proceedings are described in detail by the "GaBi" developer [22,23].

Data for the LCA model included primary data, obtained from the Blenke cascade system experiments [5] and secondary data from literature and "Lean database" like energy and emission for fertilizers and pesticides, etc. 


\subsection{Wheat Production}

The LCA model consisted of a farmland producing desired wheat grains. It was assumed that wheat was cultivated according to good agricultural practice in this area (Uni-Hohenheim farmland near the Blenke cascade pilot plant). The cultivation of wheat included the following processes: plowing, harrowing, seeds production, sowing, mechanical and chemical pest management, pesticide production, application of mineral fertilizer and the ploughing back of straw as well as the waste from bio-ethanol production plant. Harvest, transport of the harvested crops as well as, swathing and pressing of square bales were also considered.

\subsection{Bio-Ethanol Production Process}

\subsubsection{Drying and Cleaning of Wheat Grains}

Wheat grains arrived at the plant for bio-ethanol production from agricultural fields to be treated and processed. Drying and cleaning were continuous processes, executed at different rates depending on dryer capacity. In the dryer, the moisture of the grain was reduced to $13 \%-14 \%$, through a stream of air with a temperature of $\mathrm{T}=70{ }^{\circ} \mathrm{C}$ and a relative humidity of $\mathrm{RH}=70 \%$. The dryer was equipped with cyclones of $\eta=98 \%$ efficiency for recirculating drying air. Once clean, dry grain was packed and stored.

\subsubsection{Milling}

Milling is the first procedure in the bio-ethanol production process. The purpose of milling is to increase the exposure of the starch granules to water in the subsequent gelatinization process. The larger the ratio of surface area to volume of the particles, the easier it is for water and enzymes to permeate into the kernel. The desired dried wheat grains were milled by a hammer mill.

\subsubsection{Liquefaction, Saccharification and Filtration}

After milling, fine cracked wheat (14\% moisture) was hydrolysed, using enzymatic hydrolysis, in a stirring tank with a working volume of $\mathrm{V}=1000 \mathrm{~L}$. The wheat flour (dried solid) was mixed with tap water at different ratios for mash optimization and at the ratio of 1:4 for continuous bio-ethanol fermentation. Termamyl ${ }^{\circledR} \mathrm{SC}$ thermo-stable bacterial alpha-amylase (Novozymes, Bagsvaerd, Denmark) was added into the slurry at $\mathrm{C}=0.02 \%(\mathrm{v} / \mathrm{w}, \mathrm{mL} / \mathrm{kg})$ of wheat flour, when the slurry was heated to about $\mathrm{T}=55^{\circ} \mathrm{C}$ (enzyme mixture thermostable) by steam injected into the tank's jacket (steam pressure 3.8 bar). Viscozyme L of main components fungal mixed carbohydrase, beta-glucanase and cellulase (Novozymes) was added to reduce the viscosity of the mash. The slurry was continuously heated to $\mathrm{T}=95{ }^{\circ} \mathrm{C}$ and liquefied for $\mathrm{t}=60 \mathrm{~min}$. When liquefaction was complete, the mash was cooled to $\mathrm{T}=55{ }^{\circ} \mathrm{C}$ by pumping tap water into the jacket. $\mathrm{pH}$ was adjusted to $\mathrm{pH}=4.5$ by adding $\mathrm{H}_{2} \mathrm{SO}_{4}$. SAN Super $360 \mathrm{~L}$ gluco-amylase, alpha-amylase (fungal) and protease (neutral) (Novozymes) was added into the mash at $\mathrm{C}=0.04 \%(\mathrm{v} / \mathrm{w}, \mathrm{mL} / \mathrm{kg})$ of wheat flour and saccharified for $\mathrm{t}=6 \mathrm{~h}$. The saccharified mash was filtered using a high speed filter press (Ziemann, Ludwigsburg, Germany), and then used in continuous bio-ethanol fermentation in the Blenke cascade system. 


\subsubsection{Double Saccharification Principle (DSP)}

The wheat mash was stored after its first saccharification (Single Saccharification Principle-SSP). Before using the stored mash, its temperature was raised to room temperature. Then a saccharifying enzyme (SAN Super 360L) was added for the second saccharification process (Double Saccharification Principle-DSP) to increase the availability of simple sugars for fermentation.

\subsubsection{Continuous Bio-Ethanol Fermentation and In-Situ Gas Stripping}

\subsubsection{Blenke Cascade System}

The Blenke cascade system consists of the Blenke cascade, yeast separation and condensation units. The common gas lift reactor mostly is a straight column. Thus, having large axial mixing, it behaves like a single continuous stirred tank reactor (CSTR). The Blenke cascade is a special setup of gas lift reactor, which uses inserts that divide the column in several compartments. Gas introduced at the bottom of the column creates toroidal vortices in the fluid cells between inserts through buoyancy forces and entrainment, enhancing mixing and improving residence time behaviour without stirring equipment being necessary. The inserts are composed of ring-like baffles (so-called donuts) at the wall of the cascade, deflecting the flow to the center as well as disc-shaped baffles in the center of the cascade, deflecting the flow towards the column wall. They alternate with each other, thus forming the boundaries for cell flow. The yeast separation comprises of an enhanced sedimentation rate settler connected in series with a small conventional gravitational settler. The condensation unit is a series of condensers controlled by an external circulating refrigerator (for more details refer to [5]).

\subsubsection{Continuous Process}

Continuous bio-ethanol fermentation experiments were carried out in a Blenke cascade system, comprising of a Blenke cascade with a working volume of $\mathrm{V}_{1}=8.5 \mathrm{~L}$ and $\mathrm{V}_{2}=18 \mathrm{~L}$ for fermentation-stripping and yeast culturing respectively, the condensation unit and the sedimentation unit. The reactors were designed to have good mixing characteristics without mechanical agitation using $\dot{\mathrm{V}}=60 \mathrm{~L} / \mathrm{h}$ gas stripping $\left(\mathrm{CO}_{2}\right)$. The stripping gas entered the reactor through the nozzles with distributors in the stripping section of the reactor (bottom) at right angles to the axis of the reactor. Continuous fermentations were initially started as batch runs and switched over to continuous operation, when the residual sugars within the reactor were detected to be lower than $\mathrm{C}=1 \%(\mathrm{~g} / \mathrm{L})$.

\subsubsection{Condensation}

Carbon dioxide $\left(\mathrm{CO}_{2}\right)$ gas from a $\mathrm{CO}_{2}$-cylinder was supplied to the reactor through a nozzle to mix the fermentation broth. This also prevented yeast inhibition by stripping the ethanol from the broth. The bio-ethanol vapours that were stripped from the fermentor entered a condenser above the fermentor. Then the vapour was cooled to $\mathrm{T}=-3{ }^{\circ} \mathrm{C}$ and condensed to liquid, leaving uncondensed $\mathrm{CO}_{2}$ in the vapour phase to be recirculated. 


\subsubsection{Downstream Processing}

The fermentation broth from the Blenke cascade system is to be subjected to further separation in a distillation tower. Here, the azeotropic vapour of $95.6 \mathrm{wt} \%$ ethanol and $4.4 \mathrm{wt} \%$ water is withdrawn from the top and sent to an adsorption unit. The water stream from the bottom is sent back to the fermentor. Water in the top stream is adsorbed in this unit and ethanol purity in the product stream reaches $\mathrm{C}=99.5 \%$ (the minimum purity required for ethanol to be blended with gasoline and used in vehicles).

The adsorption unit consists of two adsorption columns that run cyclically between the adsorption and desorption phases. Molecular sieves are packed in the column as the adsorbents. The sieves consist of a microporous substance designed to separate small polar molecules from larger nonpolar ones via a sieving action. Water molecules are trapped and adsorbed inside the microporous beads while the ethanol molecules flow around them. Molecular sieves are then regenerated by heat and carrier air.

Distillation data and processes of the distillery were extracted and adopted from Fleischer and Senn [24] and implemented into the model. Madson [25] and Vane [26] found that the molecular sieve systems added 1 to $2 \mathrm{MJ}-\mathrm{fuel} / \mathrm{kg}-\mathrm{EtOH}$ to the heat integrated azeotropic distillation systems. Here, $1 \mathrm{MJ}$ electrical energy is equivalent to $3 \mathrm{MJ}$ fuel equivalent (MJ-fuel) and $1 \mathrm{MJ}$ thermal energy to $1.1 \mathrm{MJ}$ fuel equivalent. This was included in our model.

\subsection{Conceptual Basis of LCA}

The technical framework for the LCA methodology, as defined in ISO 14040, consists of four phases:

1. Goal and scope definition - defining purpose, audiences and system boundaries;

2. Inventory analysis - collecting data for each unit process regarding all relevant inputs and outputs of energy and mass flow, as well as data on emissions to air, water and land;

3. Impact assessment - evaluates potential environmental impacts and estimates the resources used in the modelled system and consists of three mandatory elements: selection of impact categories, classification and characterization. Classification of the life cycle inventory results involves assigning the emissions, wastes and resources used to the impact categories chosen. The converted life cycle inventory results are aggregated into an indicator result, which is the final result of the mandatory part of a life cycle impact assessment. Normalization, grouping, weighting and additional life cycle impact assessment data quality analysis are optional steps.

4. Interpretation-identifies significant issues, evaluates findings to reach conclusions and formulate recommendations. The final report is the last element to complete the phases of LCA according to ISO 14040. Regarding methodology, various LCA tools have been developed and made available for use in environmental assessment [6].

\subsubsection{Goal and Scope Definition}

The objective of this study was to develop a model containing two scenarios with the objective to comparing different pathways for the conversion of wheat grain into bio-ethanol using Blenke cascade system regarding energy output and environmental effects. 


\subsubsection{Functional Unit (FU)}

According to ISO standards, the functional unit (FU) is defined as a quantified performance of a product system to be used as a reference unit in an LCA [6,7]. In this work, the FU for each scenario was based on the production of $1 \mathrm{~kg}$ of bio-ethanol from different bio-ethanol production pathways. The selection of this FU facilitates the comparison between both options. This FU was considered to be the most appropriate one according to the objectives of the study and to the distinct products under evaluation.

\subsubsection{System Boundary and Definition}

The processes in this analysis were defined by the following system boundaries:

1. Wheat production and supply (cultivation and harvest; drying and storage; transportation to ethanol plants)_emissions and fossil energy from fertilizers and pesticides; fossil fuels used by agricultural machinery;

2. Ethanol production in Blenke cascade system - emissions from steam from natural gas (NG) or hard coal (HC), natural gas replaced by biogas (NGR), hard coal replaced by biogas (NCR) and grid-imported electricity and;

3. End product transportation to admixture facilities-emissions from transporting wheat to mills and ethanol to admixture facilities, occurs from fossil fuel use by trucks.

The following emissions and energy sources were not considered in this study as they are not included in the Renewable Energy Directive (RED) methodology: machinery, equipment and facility construction as well as human work.

Different scenarios system boundary studied were:

Scenario 1: Bio-ethanol production in Blenke cascade system without the utilization of the co-products;

Scenario 2: Bio-ethanol production in Blenke cascade system with the utilization of the co-products. Scenarios boundaries are depicted in Figures 1 and 2.

\subsection{Life Cycle Energy Analysis}

The life cycle energy analysis of bio-ethanol production was conducted by evaluating direct and indirect energy input (electricity, diesel, gasoline, fuel oil, energy from biomass, energy accumulated in fertilizers, agrochemicals, and chemical production). Equipment and machinery used in the processes were excluded.

\subsubsection{Energy Performance Calculation}

It aims to assess the life cycle consumption of the bio-ethanol production, including raw wheat farming, harvesting, mash production, transportation, ethanol conversion and purification. Based on the energy input and output for $1 \mathrm{~kg}$ of $\mathrm{C}=99.5 \%$ bio-ethanol, the net energy ratio (NER) and the net energy value or gain (NEV or NEG) can be estimated by Equations $(1,2)$ respectively [27].

$$
\begin{gathered}
N E R=E_{F} / E_{I} \\
N E V=N E G=E_{F}-E_{I}
\end{gathered}
$$


where $E_{F}$ is an energy output, which is the heating value of the fuel ethanol $(26.8 \mathrm{MJ} / \mathrm{kg}) ; E_{I}$ is the amount of total primary energy inputs to produce $1 \mathrm{~kg}$ of ethanol. The NEG is a key indicator to identify whether ethanol production and utilization results in a gain or loss of energy. The energy credits were calculated using substitution and allocation methods in $\mathrm{GaBi}$ 4.3.

\subsubsection{Life-Cycle Impact Assessment}

The inventory data from each phase were compiled in GaBi 4.3. CML 2010 method was used to evaluate the environmental impacts of bio-ethanol produced in the Blenke cascade system. The impact categories were: abiotic depletion (ADP), acidification (AP), eutrophication (EP), global warming (GWP), human toxicity (HTP), ozone layer depletion (ODP) and photochemical ozone creation (POCP) potential.

Figure 1. Production pathways for bio-ethanol with Blenke cascade system for Scenario 1. Note: * Blenke cascade processes (for more detail see [5]).

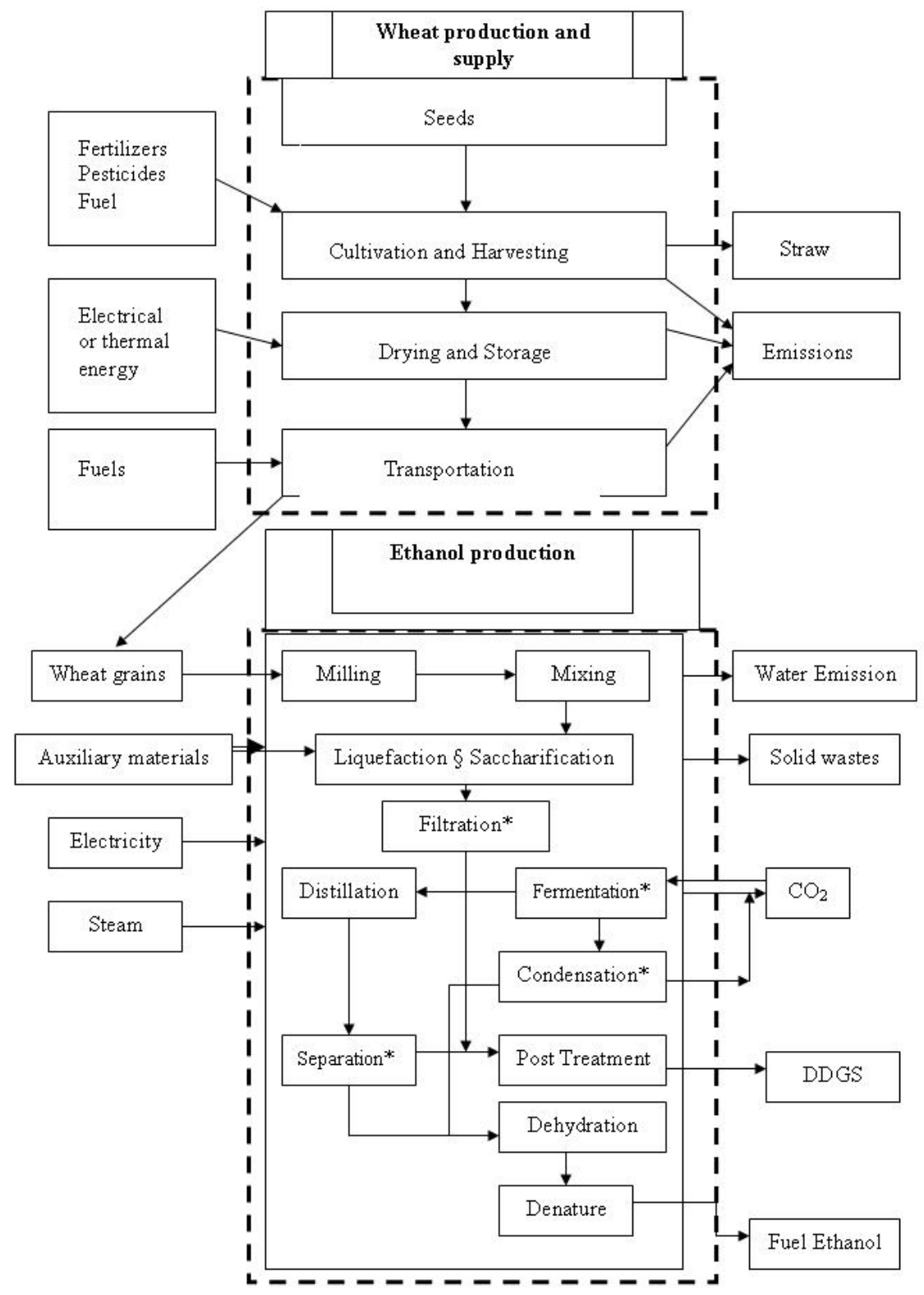


Figure 2. Production pathways for bio-ethanol with Blenke cascade system for Scenario 2.

Note: * Blenke cascade system processes (for more detail see [5]).

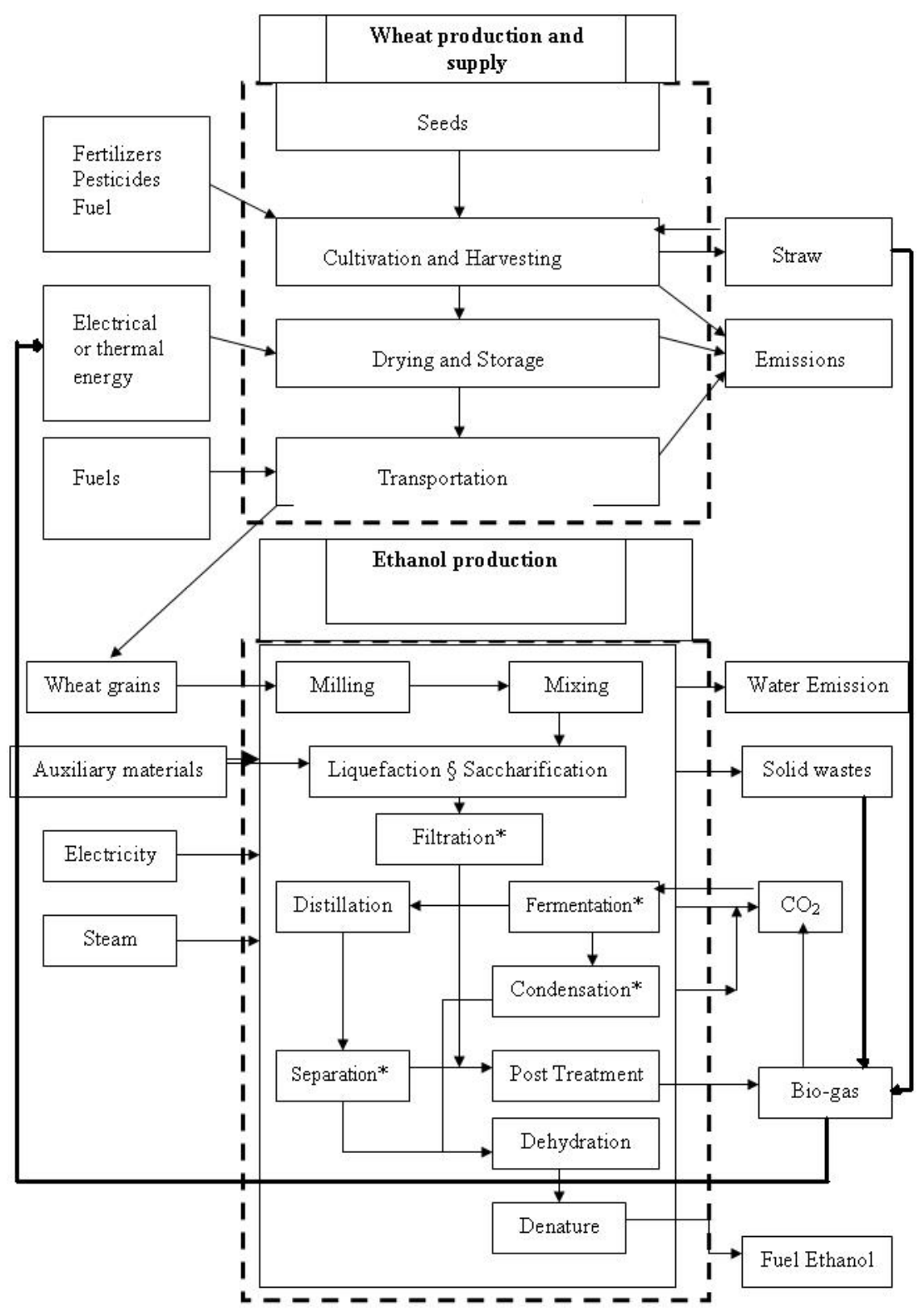

\section{Results and Discussions}

\subsection{Results from Energy Analysis}

The energy input in the product system was divided into three main stages: Energy used in wheat cultivating and harvesting, in transportation and in ethanol conversion. The cake and dried distiller grains with soluble (DDGS) were used as fertilizers in food production lands near the Blenke cascade pilot plant in scenario 1 and used in biogas for power generation in scenario 2 . Appendixes 1 and 2 depict basic input data of the three stages.

In scenario 1, the electrical power required in ethanol conversion was from power grid mix (Germany) and the steam was from process steam, either created by natural gas or hard coal. In case of natural gas, the production of $1 \mathrm{~kg}$ of wheat ethanol required a total primary energy input of $23 \mathrm{MJ}$ 
while it was 23.9 MJ for hard coal. Fertilizers from cake and DDGS resulted in 1.6 MJ credit in both cases. The energy consumption was the highest in the ethanol conversion stage $(54.8 \%$ and $56.4 \%$ of the total energy input for natural gas and hard coal respectively) followed by the wheat cultivating and harvesting stage $(39.5 \%$ and $38.1 \%)$. The transportation stage consumed relatively low energy in the life cycle $(5.7 \%$ and $5.5 \%)$. The comparison between the energy output and input showed that NEG and $\mathrm{NER}$ were $3.8 \mathrm{MJ} / \mathrm{kg}$ ethanol and $1.16 \mathrm{MJ} / \mathrm{MJ}$ fossils respectively in case of natural gas and $2.9 \mathrm{MJ} / \mathrm{kg}$ ethanol and $1.12 \mathrm{MJ} / \mathrm{MJ}$ fossils for hard coal.

In scenario 2, steam and electrical power requirements were from a co-products utilization (bio-gas) in order to promote a self-sufficient system. The primary energy needed to produce $1 \mathrm{~kg}$ of ethanol was reduced by $70.2 \%$ and $72.05 \%$ in case of biogas replacing natural gas and hard coal respectively. Here, the wheat cultivating and harvesting stage contributed to more than $85 \%$ of the total primary energy. In addition to the energy credit from cake and DDGS (1.12 MJ/kg ethanol), the ethanol conversion stage had a credit of $2.66 \mathrm{MJ} / \mathrm{kg}$ ethanol (due to the heat recovery system). NEG and NER were $19.95 \mathrm{MJ} / \mathrm{kg}$ ethanol and 3.9 MJ/MJ fossils for natural gas replacement while it was $20.12 \mathrm{MJ} / \mathrm{kg}$ ethanol and 4.0 MJ/MJ fossils for hard coal replacement. Table 1 depicts the comparison of energy input for the two scenarios studied.

The low primary energy input in the whole life cycle of ethanol production using Blenke cascade system, especially in ethanol conversion stage, may be explained by different methods used in Blenke cascade system: use of double saccharification principle (DSP), $\mathrm{CO}_{2}$ gas mixing instead of motor, recycling of yeast and $\mathrm{CO}_{2}$ gas and heat recovery [5]. The results clearly show an energy profit for the wheat-based ethanol regardless of use or non-use of co-product (DDGS and Biogas). However, the energy profit increases more than 6 times when co-products are utilized.

Table 1. Comparison of energy input (MJ/kg-Ethanol) for scenario 1 and 2.

\begin{tabular}{ccccc}
\hline \multirow{2}{*}{ Scenario } & \multicolumn{4}{c}{ Primary energy } \\
\cline { 2 - 5 } & Natural gas & Hard coal & Natural gas replaced by Biogas & hard coal replaced by Biogas \\
\hline Scenario 1 & 23 & 23.9 & -- & -- \\
Scenario 2 & -- & -- & 6.9 & 6.7 \\
\hline
\end{tabular}

\subsection{Sensitivity Analysis}

In this study, a sensitivity analysis was done to identify the effect of some possible changes on the NEG. Using natural gas or hard coal as main source of energy in the ethanol conversion stage was treated as the base case. 4 options were considered: the influence of increasing and decreasing (1) ethanol concentration; (2) mash/water ratio; (3) mass of cake; and (4) wheat yield, by 10\% each.

Table 2 depicts sensitivity analysis of factors related to NEG displayed in MJ/kg ethanol. From this table, it can be seen, that increasing or decreasing option (2), (3) by $10 \%$, did not change the NEG significantly for both scenarios. For option (1) and (4), the NEG was significantly affected compared to other options. The analysis demonstrated that using the Blenke cascade system for wheat-based ethanol production, the energy resources were used efficiently. It is clear that the utilization of co-products (such as biogas, cake and DDGS) significantly increases wheat based bio-ethanol's energy benefits. This agrees with the conclusion of Punter et al. [28], that incorporation of CHP (combined 
heat and power generation), use of straw as an energy source and use of DDGS as energy for power generation improve efficiency. Appendixes 1 and 2 show the plan and basic input data of the ethanol production combined with CHP.

The results of cradle-to-gate inventory for the key environmental flows are presented in Table 3 . Depletion of non-renewable resources is an important criterion for decision making on alternative fuels. In scenario 1, the use of coal and natural gas was highest in ethanol conversion stage (data not shown), which also resulted in airborne emissions due to coal and natural gas burning. $\mathrm{CH}_{4}$ emission was high in both the scenarios. It was mainly from anaerobic digestion process in scenario 2 and from incomplete burning [process steam efficiency (85\%)] in scenario 1. It is interesting to note, that $\mathrm{CO}_{2}$ emission was about 21 times higher in scenario 1 than in scenario 2 . This permits one to conclude, that using the Blenke cascade system and co-products does not only increase wheat based bio-ethanol's energy benefits, but also significantly reduces the emissions.

Table 2. Sensitivity analysis of factors related to NEG displayed in MJ/kg ethanol, total primary energy input (sensitivity factor $= \pm 10 \%$ ).

\begin{tabular}{|c|c|c|c|c|c|c|c|c|c|c|}
\hline \multirow{2}{*}{ Scenario } & \multirow{2}{*}{ Steam } & \multirow{2}{*}{ Base Case } & \multicolumn{2}{|c|}{ Cake (kg) } & \multicolumn{2}{|c|}{ Ethanol conc. $(v / v \%)$} & \multicolumn{2}{|c|}{ Mash/water ratio } & \multicolumn{2}{|c|}{ Wheat yield (\%) } \\
\hline & & & $-10 \%$ & $+10 \%$ & $-10 \%$ & $+10 \%$ & $-10 \%$ & $+10 \%$ & $-10 \%$ & $+10 \%$ \\
\hline \multirow{2}{*}{ Scenario 1} & NG & 20.0 & 19.81 & 20.42 & 18.72 & 21.21 & 19.61 & 20.22 & 19.83 & 22.51 \\
\hline & $\mathrm{HC}$ & 20.3 & 20.31 & 20.73 & 18.94 & 21.22 & 19.83 & 20.42 & 19.94 & 22.05 \\
\hline \multirow{2}{*}{ Scenario 2} & NGR & 3.8 & 3.72 & 4.12 & 2.65 & 3.75 & 3.53 & 4.01 & 3.64 & 4.65 \\
\hline & HCR & 2.9 & 2.81 & 2.99 & 1.83 & 2.97 & 2.57 & 3.17 & 2.75 & 4.22 \\
\hline
\end{tabular}

Table 3. Life-cycle inventory for production of $1 \mathrm{~kg}$ anhydrous ethanol in Blenke cascade system.

\begin{tabular}{ccccc}
\hline \multirow{2}{*}{ Inventory } & \multicolumn{2}{c}{ Scenario 1 } & \multicolumn{2}{c}{ Scenario 2 } \\
\cline { 2 - 5 } & Steam from NG & Steam from HC & Steam from NG & Steam from HC \\
\hline Primary energy $(\mathrm{MJ})$ & 23 & 23.9 & 6.85 & 6.68 \\
Emissions & -- & -- & -- & -- \\
$\mathrm{CO}_{2}(\mathrm{~kg})$ & 2.6 & 2.75 & 0.107 & 0.111 \\
$\mathrm{CH}_{4}(\mathrm{~g})$ & 1.7 & 1.19 & 3.4 & 2.78 \\
$\mathrm{~N}_{2} \mathrm{O}(\mathrm{mg})$ & 0.0013 & 0.0013 & 0.0013 & 0.0013 \\
$\mathrm{NO}$ & $(\mathrm{g})$ & 6.2 & 2.37 & 2.22 \\
$\mathrm{SO}(\mathrm{g})$ & 5.46 & 6.49 & 3.83 & 5.45 \\
$\mathrm{NMVOC}_{\mathrm{M}}(\mathrm{g})$ & 5.66 & 0.507 & 0.238 & 0.258 \\
$\mathrm{BOD}(\mathrm{mg})$ & 0.61 & 3.86 & 3.13 & 3.54 \\
$\mathrm{COD}(\mathrm{g})$ & 5.97 & 0.274 & 0.246 & 0.249 \\
Nitrate $(\mathrm{g})$ & 0.288 & 32.8 & 32.7 & 32.7 \\
Phosphate $(\mathrm{g})$ & 32.7 & 0.259 & 0.221 & 0.221 \\
\hline
\end{tabular}

\subsection{Results from Impact Assessment}

The life cycle environmental assessment is depicted in Figure 3. Scenario 1 using steam from hard coal had a significant impact on global warming and humanity toxicity potentials. This is due to the fact, that coal is a non-renewable energy resource and burning coal generates more $\mathrm{CO}_{2}, \mathrm{SO}_{\mathrm{X}}$ and $\mathrm{NO}_{\mathrm{X}}$ than other fuels, which contribute to global warming, acidification, human toxicity and abiotic 
depletion (linked to the use of hard coal). This is in line with the finding of Papong and Malakul [29]. In case of scenario 2, the impact was significant on global warming potential. This is due to the addition of $\mathrm{CH}_{4}$ emission from anaerobic digestion.

Comparing the scenario 1 and 2, the environmental impacts in scenario 2 were lesser than those in scenario 1, except for abiotic depletion which was almost the same for both scenarios. It was interesting to note that the impact category human toxicity potential was reduced by almost 10 times using biogas. In general, using Blenke cascade system and co-products, environmental impacts were reduced significantly and some were almost non-existent.

Figure 3. Impact assessment comparisons between Scenarios.

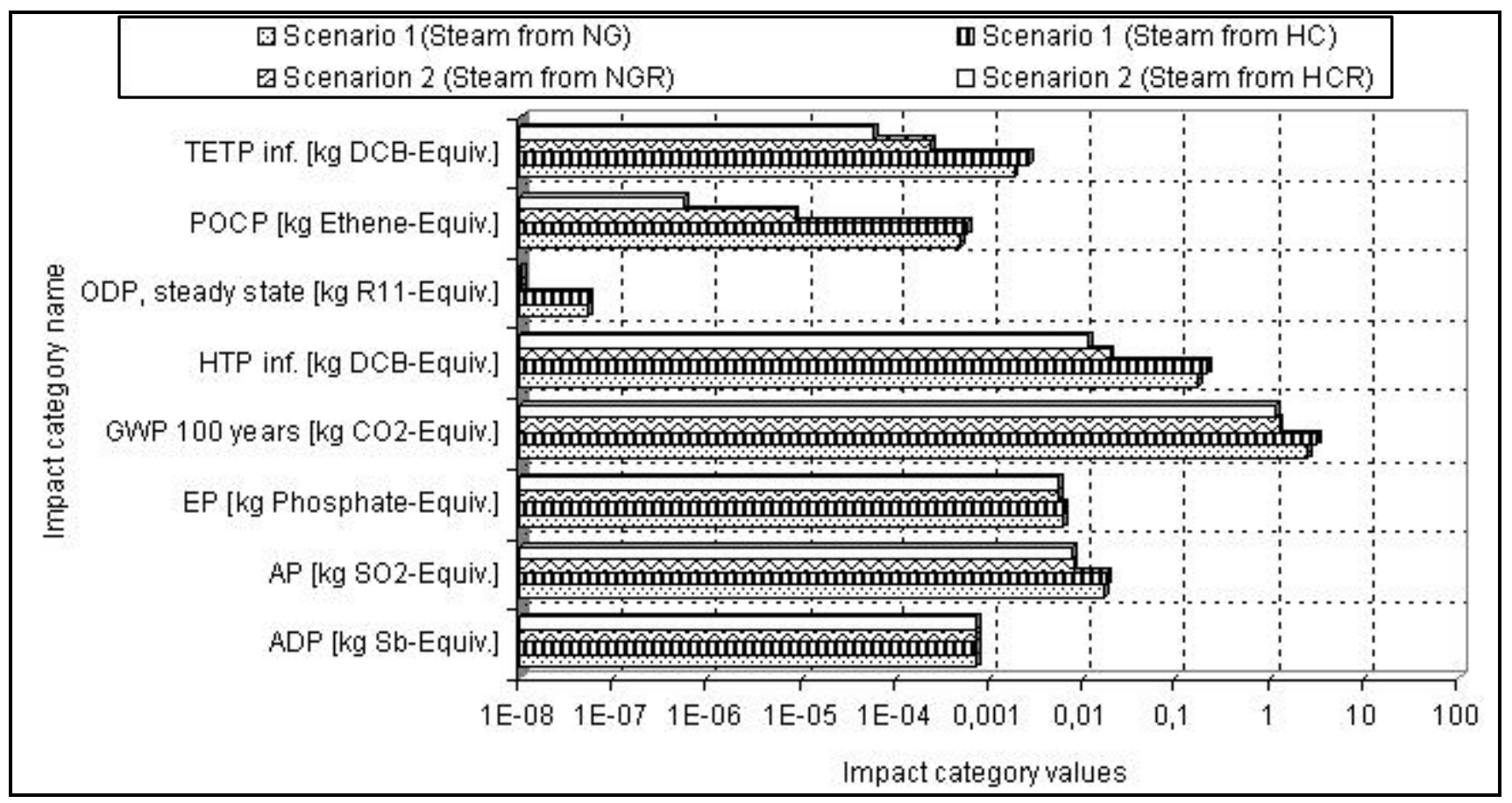

\subsection{Improvement of the Environmental Performance and Energy Efficiency}

The Blenke cascade system was developed for ethanol production and was found to reduce energy and emissions. Carbon dioxide gas produced was not allowed to diffuse to atmosphere. It was recycled in the Blenke cascade reactor. Recycling of yeast reduced the use of fresh yeast, thereby, reducing the emissions from the yeast manufacturing industries. Energy recovery reduces heat loss. The emission from power grid mix was reduced by reducing electrical power needed for mixing by introducing gas as mixing tool. The use of double saccharification principle and co-products utilisation [5] reduced emissions. All of the above contributed to the significant energy efficiency environmental performance.

\subsection{Comparison with Other Wheat-Based Ethanol LCA Studies}

Several studies had analysed the production of bio ethanol based on wheat and estimated the fossil energy demands. Austmeyer and Röver [30] found that the energy use for ethanol conversion stage was $16 \mathrm{MJ} / \mathrm{L}$ ethanol, and a total energy of around $26 \mathrm{MJ} / \mathrm{L}$ ethanol (cradle-to-gate). The International Energy Agency [31] studying the prognosis for future technologies predicted less than $10 \mathrm{MJ}$ for the 
ethanol conversion stage and a total energy of around $16 \mathrm{MJ} / \mathrm{L}$ of bio-ethanol from different ethanol production systems. Power et al. [32] estimated the net energy demand with a focus on energy being utilized in the process of ethanol formation. They found that the total electric energy required in the production is $0.32 \mathrm{kWh}$ and the amount of thermal energy required is $2.4 \mathrm{kWh} / \mathrm{L}$ of ethanol produced. Comparing our results of total energy values of 6-24 MJ/kg ethanol with the above mentioned studies shows that Blenke cascade system yielded better results.

$\mathrm{Yu}$ and Tao [33] presented the LCA of biomass-based fuel ethanol projects in different regions in China. They showed that with energy credit from co-products, that wheat-based fuel ethanol productions has a positive NEV with an energy return on energy invested ratio of $1.454 \mathrm{MJ} / \mathrm{MJ}$ fossil. Our LCA results with Blenke cascade system with an energy efficiency of 1.15-4 MJ/MJ fossils depending on the source of steam used in ethanol conversion stage and utilization of co-products seem to be more promising.

\section{Conclusions}

In this study, the life-cycle energy and environmental evaluation for wheat-based bio-ethanol production in Blenke cascade system was performed. In the Blenke cascade system with co-products utilisation (scenarion 2), the primary energy needed to produce $1 \mathrm{~kg}$ of wheat ethanol was reduced by $70.2 \%$ and $72.05 \%$ in case of replacement of natural gas and from hard coal respectively by biogas. In scenario 1 , the energy usage was highest $(>50 \%)$ in bio-ethanol conversion stage, while in scenario 2 , it was highest in wheat farming and harvesting ( $>70 \%)$. Comparing scenario 1 and 2 , the environmental impacts in scenario 2 were less than those in scenario 1.

In conclusion, the use and recycling of $\mathrm{CO}_{2}$, yeast recycling, energy recovery, electrical power reduction, double saccharification principle and co-products utilization in the Blenke cascade system resulted in a low primary energy input and a good environmental performance in the whole life cycle of ethanol production.

\section{Acknowledgements}

We would like to acknowledge the DAAD (German Academic Exchange Service) for its financial support of J.N. Ntihuga at Hohenheim University.

\section{References}

1. Reijnders, L.; Huijbregts, M.A.J. Life cycle greenhouse gas emissions, fossil fuel demand and solar energy conversion efficiency in European bioethanol production for automotive purposes. J. Clean Prod. 2007, 15, 1806-1812.

2. Mizsey, P.; Racz, P. Cleaner production alternatives: Biomass utilisation options. J. Clean Prod. 2010, 18, 767-770.

3. European Commission. Proposal for a Council Regulation on the Common Organization of the Market in Ethyl Alcohol of Agricultural Origin; 6586/01 COM(2001) 101 Final Subject; European Commission: Brussels, Belgium, 2001. 
4. Yang, H.; Chen, L.; Yan, Z.; Wang, H. Energy analysis of cassava-based fuel ethanol in China. Biomass Bioenergy 2011, 35, 581-589.

5. Ntihuga, J.N.; Senn, T.; Gschwind, P.; Kohlus, R. Efficiency of Blenke cascade system for continuous bio-ethanol fermentation. Bioresour. Technol. 2012, 123, 221-229.

6. International Organization for Standardization (ISO). Environmental Management-Life Cycle Assessment_Principles and Framework; ISO 14040:2006; ISO: Geneva, Switzerland, 2006.

7. ISO. Environmental Management-Life Cycle Assessment-Requirements and Guidelines; ISO 14044:2006; ISO: Geneva, Switzerland, 2006.

8. Bai, Y.; Luo, L.; van der Voet, E. Life cycle assessment of switch grass-derived ethanol as transport fuel. Int. J. Life Cycle Assess. 2010, 15, 468-477.

9. Hu, Z.; Fang, F.; Ben, D.F.; Pu, G.; Wang, C. Net energy, $\mathrm{CO}_{2}$ emission, and life-cycle cost assessment of cassava-based ethanol as an alternative automotive fuel in China. Appl. Energy 2004, 78, 247-256.

10. García, C.A.; Fuentes, A.; Hennecke, A.; Riegelhaupt, E.; Manzini, F.; Masera, O. Lifecycle greenhouse gas emissions and energy balances of sugarcane ethanol production in Mexico. Appl. Energy 2011, 88, 2088-2097.

11. Luo, L.; van der Voet, E.; Huppes, G. An energy analysis of ethanol from cellulosic feedstock — Corn stover. Renew. Sustain. Energy Rev. 2009, 13, 2003-2011.

12. Nguyen, T.L.T.; Gheewala, S.H. Life cycle assessment of fuel ethanol from cane molasses in Thailand. Int. J. Life Cycle Assess. 2008, 13, 301-311.

13. Yee, K.F.; Tan, K.T.; Abdullah, A.Z.; Lee, K.T. Life cycle assessment of palm biodiesel: Revealing facts and benefits for sustainability. Appl. Energy. 2009, 86, S189-S196.

14. Achten, W.M.J.; Almeida, J.; Fobelets, V.; Bolle, E.; Mathijs, E.; Singh, V.P.; Tewari, D.N.; Verchot, L.V.; Muys, B. Life cycle assessment of Jatropha biodiesel as transportation fuel in rural India. Appl. Energy. 2010, 87, 3652-3660.

15. Dufour, J.; Iribarren, D. Life cycle assessment of biodiesel production from free fatty acid-rich wastes. Renew. Energy 2012, 38, 155-162.

16. Sanz Requena, J.F.; Guimaraes, A.C.; Alpera, S.Q.; Gangas, E.R.; Hernandez-Navarro, S.; Navas Gracia, L.M.; Martin-Gil, J.; Fresneda Cuesta, H. Life cycle assessment (LCA) of the biofuel production process from sunflower oil, rapeseed oil and soybean oil. Fuel Process. Technol. 2011, 92, 190-199.

17. Eriksson, O.; Finnveden, G.; Ekvall, T.; Björklund, A. Life cycle assessment of fuels for district heating: a comparison of waste incineration, biomass- and natural gas combustion. Energy Policy 2007, 35, 1346-1362.

18. Heller, M.C.; Keoleian, G.A.; Mann, M.K.; Volk, T.A. Life cycle energy and environmental benefits of generating electricity from willow biomass. Renew. Energy 2004, 29, 1023-1042.

19. Kimming, M.; Sundberg, C.; Nordberg, Å.; Baky, A.; Bernesson, S.; Norén, O.; Hansson, P. Biomass from agriculture in small-scale combined heat and power plants-A comparative life cycle assessment. Biomass Bioenergy 2011, 35, 1572-1581.

20. González-García, S.; Iribarren, D.; Susmozas, A.; Dufour, J.; Murphy, R.J. Life cycle assessment of two alternative bioenergy systems involving Salix spp. Biomass: Bio-ethanol production and power generation. Appl. Energy 2012, 95, 111-122. 
21. GaBi 4; Software und Datenbank zur Ganzheitlichen Bilanzierung [in German]; PE International GmbH: Leinfelden-Echterdingen, Germany, 2006.

22. Eyerer, P.; Saur, K. Die Ganzheitliche Bilanzierung [in German]. In Definition, Geschichte, Hintergründe, in Ganzheitliche Bilanzierung. Werkzeug zum Planen und Wirtschaften in Kreisläufen; Eyerer, P., Ed.; Springer: Berlin, Germany, 1996; pp. 1-26.

23. Florin, H.; Pfleiderer, I.; Volz, T. Software zur Ganzheitlichen Bilanzierung [in German]. In Definition, Geschichte, Hintergründe, in Ganzheitliche Bilanzierung. Werkzeug zum Planen und Wirtschaften in Kreisläufen; Eyerer, P., Ed.; Springer: Berlin, Germany, 1996; pp. 181-209.

24. Fleischer, S. Verbesserung der Energie-, Stoff- und Emissionsbilanzen bei der Bioethanolproduktion aus nachwachsenden Rohstoffen [in German]. Ph.D. Thesis, University of Hohenheim, Stuttgart, Germany, 2010.

25. Madson, P.W. Fuel Ethanol Feedstock Challenges. Presented at the Montana Symposium, Energy Future of the West, Bozeman, MT, USA, 18-19 October 2005.

26. Vane, L.M. Separation technologies for the recovery and dehydration of alcohols from fermentation broths. Biofuels Bioprod. Bioref. 2008, 2, 553-588.

27. Papong, S.; Noksa-nga, S.; Chom-in, T.; Malakul, P. Life Cycle Energy and Environmental Evaluation of Molasses-Based Ethanol Production for Commercial Scales in Thailand. In Proceedings of International Conference on Environmental Research and Technology, Penung, Malaysia, 28-30 May 2008.

28. Punter, G.; Rickeard, D.; Larivé, J.F.; Edwards, R.; Mortimer, N.; Horne, R.; Bauen, A.; Woods, J. Well-to-Wheel Evaluation for Production of Ethanol from Wheat; A Report by the Low CVP Fuels Working Group, WTW Sub-Group No. FWG-P-04-024; Low Carbon Vehicle Partnership (LowCVP): London, UK, 2004.

29. Papong, S.; Malakul, P. Life cycle energy and environmental analysis of bioethanol production from cassava in Thailand. Bioresour. Technol. 2010, 101, S112-S118.

30. Austmeyer, K.; Röver, H. Verbundproduktion von Ethanol und Weißzucker [in German]. Zuckerindustrie 1998, 113, 765-772.

31. International Energy Agency (IEA). Biofuels; IEA: Paris, France, 1994.

32. Power, N.; Murphy, J.D.; McKeogh, E. What crop rotation will provide optimal first-generation ethanol production in Ireland, from technical and economic perspectives? Renew. Energy 2008, $33,1444-1454$.

33. Yu, S.; Tao, J. Economic, energy and environmental evaluations of biomass-based fuel ethanol projects based on life cycle assessment and simulation. Appl. Energy 2009, 86, S178-S188. 


\section{Appendix}

\section{Appendix 1. Parameters Used in Life Cycle Assessment for Ethanol Production Using Blenke Cascade System}

Table A1. Parameters used in the life cycle analysis at the first stage (cultivation and harvesting).

\begin{tabular}{cc}
\hline Parameter & Value \\
\hline Diesel required for cultivation and fertilising $(\mathrm{kg} / \mathrm{ha})^{*}$ & 29.16 \\
Ammonium nitrate $(\mathrm{solid})(\mathrm{kg} / \mathrm{ha})^{*}$ & 215 \\
Raw phosphate $\left(32.4 \% \mathrm{P}_{2} \mathrm{O}_{5}\right)(\mathrm{kg} / \mathrm{ha}) *$ & 33 \\
Potassium chloride $\left(60 \% \mathrm{~K}_{2} \mathrm{O}\right)(\mathrm{kg} / \mathrm{ha}) *$ & 100 \\
Trifluralin $(\mathrm{kg} / \mathrm{ha}) *$ & 3 \\
Benomyl $(\mathrm{kg} / \mathrm{ha}) *$ & 3 \\
\hline
\end{tabular}

Note: * GaBi Lean database.

Table A2. Parameters used in the life cycle analysis at the second stage (transportation).

\begin{tabular}{cc}
\hline Assumptions & Value \\
\hline Distance $(\mathrm{km}) *$ : & 50 \\
from farmland to a milling station & 50 \\
from milling station- to a Blenke cascade pilot plant & 100 \\
\hline from Blenke cascade pilot plant to a denatured ethanol delivery station & \\
\hline
\end{tabular}

Note: * from GaBi Lean database for using truck-trailer * (truck fleet, local).

Table A3. Parameters used in the life cycle analysis at the third stage (ethanol conversion).

\begin{tabular}{cc}
\hline Parameters * & Value \\
\hline Liquefaction & $1.12 \times 10^{-4}$ \\
Mass of the enzyme Thermamyl $(\mathrm{kg})$ & 0.28 \\
The mass of the flour in $\mathrm{kg}$ & 100 \\
Flow rate of the steam in $\mathrm{kg} / \mathrm{h}$ & 200 \\
Flow rate of water in $\mathrm{kg} / \mathrm{h}$ & 0.76 \\
Enthalpy of the steam in $\mathrm{kWh}$ & 103.8 \\
Power required for mixing during liquefaction & 180 \\
Power required for pumping water in $\mathrm{kWh}$ & 0.3 \\
Time required for pumping water in hours & 45 \\
Rotation of agitator in rpm & 0.25 \\
Starch content in $\mathrm{kg}$ & 0.5 \\
Time required for rising temperature from $20{ }^{\circ} \mathrm{C}$ to $85{ }^{\circ} \mathrm{C}$ & 1 \\
Lliquefaction time in hours & 1 \\
Mass of water in $\mathrm{kg}$ & 4.19 \\
Saccharification & -32 \\
\hline Specific heat of water $\left[\mathrm{kJ} /\left(\mathrm{kg}{ }^{\circ} \mathrm{C}\right)\right]$ & $1.4 \times 10^{-4}$ \\
Temperature different in c & 0.28 \\
\hline SAN Super enzyme for saccharification $(\mathrm{L})$ & Flour content $(\mathrm{kg})$ \\
\hline
\end{tabular}


Table A3. Cont.

\begin{tabular}{|c|c|}
\hline Parameters * & Value \\
\hline \multicolumn{2}{|l|}{ Saccharification } \\
\hline Flow rate of steam $(\mathrm{kg})$ & 100 \\
\hline Flow rate of cooling water $\mathrm{L} / \mathrm{h}$ & 500 \\
\hline Flow rate of water $(\mathrm{kg} / \mathrm{h})$ & 500 \\
\hline Enthalpy of steam kWh & 0.76 \\
\hline Power for mixing in $\mathrm{kWh}$ & 103.8 \\
\hline Agitator speed in rpm & 45 \\
\hline Starch content $(\mathrm{kg})$ & 0.224 \\
\hline Cooling time $(\mathrm{h})$ & 1 \\
\hline Time for saccharification $(\mathrm{h})$ & 5 \\
\hline Water content $(\mathrm{kg})$ & 1 \\
\hline \multicolumn{2}{|l|}{ Saccharified mash } \\
\hline Density of the cake $(\mathrm{kg} / \mathrm{L})$ & 0.85 \\
\hline Volume of the cake obtained (L) & 187 \\
\hline Density of the filtrate obtained $(\mathrm{kg} / \mathrm{L})$ & 1.13 \\
\hline Volume of the filtrate (L) & 545 \\
\hline Flow rate of the mash $(\mathrm{kg} / \mathrm{h})$ & 3176 \\
\hline Power needed for filtration(kWh) & 240 \\
\hline Duration of saccharified mash filtration (h) & 0.5 \\
\hline \multicolumn{2}{|l|}{ Batch fermentation } \\
\hline Yeast extract needed in $(\mathrm{kg} / \mathrm{L})$ & 0.01 \\
\hline Density of the filtrate $(\mathrm{kg} / \mathrm{L})$ & 1.13 \\
\hline Volume of filtrate $\mathrm{L}$ & 3.5 \\
\hline Stripping gas flow rate at $1 \mathrm{bar}(\mathrm{L} / \mathrm{h})$ & 60 \\
\hline Duration of stripping $(\mathrm{h})$ & 6 \\
\hline Density of the stripping gas (carbon dioxide) $(\mathrm{kg} / \mathrm{L})$ & $1.43 \times 10^{-2}$ \\
\hline Power needed for controlling the fermentation temperature of $33{ }^{\circ} \mathrm{C}(\mathrm{kWh})$ & $4.6 \times 10^{-2}$ \\
\hline Yeast needed $(\mathrm{kg} / \mathrm{L})$ & 0.01 \\
\hline \multicolumn{2}{|l|}{ Substrate tank } \\
\hline Filtered mash density $(\mathrm{kg} / \mathrm{L})$ & 1.13 \\
\hline Flow rate of substrate $(\mathrm{L} / \mathrm{h})$ & 1 \\
\hline Power required to keep the substrate homogeneous in $\mathrm{kWh}$ & $2.5 \times 10^{-2}$ \\
\hline Batch time (h) & 6 \\
\hline \multicolumn{2}{|l|}{ Continuous fermentation } \\
\hline Extract needed $(\mathrm{kg})$ & $5 \times 10^{-5}$ \\
\hline Ethanol content per litre of the beer $(\mathrm{kg})$ & 0.01 \\
\hline Ethanol stripped in $\mathrm{kg}$ & $7 \times 10^{-3}$ \\
\hline Conversion factor related to Carbon dioxide & 0.49 \\
\hline Conversion factor related to Ethanol & 0.51 \\
\hline Density of the beer going to sedimentation tank $(\mathrm{kg} / \mathrm{L})$ & 0.98 \\
\hline Flow rate of the beer $(\mathrm{L} / \mathrm{h})$ & 1.86 \\
\hline Power required to pump the substrate solution to the Cascade $(\mathrm{kWh})$ & $6 \times 10^{-3}$ \\
\hline Power needed to pump yeast solution to the Cascade $(\mathrm{kWh})$ & $6 \times 10^{-3}$ \\
\hline Flow rate of the substrate solution $(\mathrm{L} / \mathrm{h})$ & 1 \\
\hline
\end{tabular}


Table A3. Cont.

\begin{tabular}{|c|c|}
\hline Parameters * & Value \\
\hline \multicolumn{2}{|l|}{ Continuous fermentation } \\
\hline Density of the substrate $(\mathrm{kg} / \mathrm{L})$ & 1.13 \\
\hline Flow rate of the stripping gas $(\mathrm{L} / \mathrm{h})$ & 60 \\
\hline Time taken for the fermentation with stripping (h) & 1 \\
\hline Density of the stripping gas $(\mathrm{kg} / \mathrm{L})$ & $1.43 \times 10^{-2}$ \\
\hline Power needed to keep substrate solution homogenuous $(\mathrm{kWh})$ & $2.5 \times 10^{-2}$ \\
\hline Power needed for temperature control equipment $(\mathrm{kWh})$ & $4.6 \times 10^{-2}$ \\
\hline Yeast needed $(\mathrm{kg})$ & $5 \times 10^{-3}$ \\
\hline Yeast going out along with beer $(\mathrm{kg})$ & $2 \times 10^{-3}$ \\
\hline Density of the yeast solution in $(\mathrm{kg} / \mathrm{L})$ & 1.01 \\
\hline Flow rate of the yeast-Extract slolution $(\mathrm{kg} / \mathrm{L})$ & 0.5 \\
\hline Power needed to keep yeast solution homogenuous (kWh) & $2.5 \times 10^{-2}$ \\
\hline \multicolumn{2}{|l|}{$\begin{array}{l}\text { Striped-condensation } \\
\end{array}$} \\
\hline Ahydrous ethanol from the fermentation process $(\mathrm{kg})$ & $6.8 \times 10^{-2}$ \\
\hline Carbon dioxide gas produced in $\mathrm{kg}$ & $6.5 \times 10^{-2}$ \\
\hline Heat needed for condensation of Ethanol $(\mathrm{kJ})$ & 41.19 \\
\hline Specific heat for Ethanol $\left[\mathrm{kJ} /\left(\mathrm{kg}^{\circ} \mathrm{C}\right)\right]$ & 2.46 \\
\hline specific heat for water $\left[\mathrm{kJ} /\left(\mathrm{kg}{ }^{\circ} \mathrm{C}\right)\right]$ & 4.19 \\
\hline Heat capacity of Ethanol $\left[\mathrm{kJ} /\left({ }^{\circ} \mathrm{C}\right)\right]$ & 844 \\
\hline Heat capacity of water $\left[\mathrm{kJ} /\left({ }^{\circ} \mathrm{C}\right)\right]$ & 1213.3 \\
\hline Temperature difference $\left({ }^{\circ} \mathrm{C}\right)$ & 35 \\
\hline Total ethanol going to sedimentation $(\mathrm{kg})$ & $1.2 \times 10^{-2}$ \\
\hline Ethanol stripped $(\mathrm{kg})$ & $4.9 \times 10^{-2}$ \\
\hline Ethanol contains in $1 \mathrm{~L}$ of beer $(\mathrm{kg})$ & $1.0 \times 10^{-2}$ \\
\hline Average Ethanol stripped in $\mathrm{h}(\mathrm{kg})$ & $7 \times 10^{-3}$ \\
\hline Ethanol ratio & $7 \times 10^{-4}$ \\
\hline Conversion factor to Carbon dioxide & 0.49 \\
\hline Conversion factor to ethanol & 0.51 \\
\hline Flow rate of the beer to the sedimentation tank $(\mathrm{L} / \mathrm{h})$ & 1.86 \\
\hline density of the beer $(\mathrm{kg} / \mathrm{L})$ & 0.98 \\
\hline Glucose converted into Ethanol kg & 0.13 \\
\hline Electrical power needed for Heat Exchanger system $(\mathrm{kJ})$ & 2945 \\
\hline Sensible heat of Ethanol kJ & 0.17 \\
\hline Sensible heat for water $\mathrm{kJ}$ & 37.77 \\
\hline Latent heat of Ethanol (kJ) & 41.36 \\
\hline Latent heat of water stripped $\mathrm{kJ}$ & 1212.45 \\
\hline Stripping gas flow rate in $\mathrm{L} / \mathrm{h}$ & 60 \\
\hline Total time for the fermentation process $(\mathrm{h})$ & 7 \\
\hline Duration of the batch fermentation (h) & 6 \\
\hline Duration of continous fermentation with stripping (h) & 1 \\
\hline Density of the stripping gas $\mathrm{kg} / \mathrm{L}$ ) & $1.14 \times 10^{-2}$ \\
\hline Supplied Stripping gas $(\mathrm{kg})$ & 6.01 \\
\hline Total gas out going in Condensation $(\mathrm{kg})$ & 6.07 \\
\hline Water stripped $(\mathrm{kg})$ & 0.1 \\
\hline
\end{tabular}


Table A3. Cont.

\begin{tabular}{|c|c|}
\hline Parameters * & Value \\
\hline \multicolumn{2}{|l|}{ Sedimentation } \\
\hline Beer going in Sedimentor in $(\mathrm{kg} / \mathrm{h})$ & 1.83 \\
\hline Product to be sent to Distillation $(\mathrm{kg} / \mathrm{h})$ & 1.69 \\
\hline Concentration of the Ethanol in beer $(\mathrm{kg} / \mathrm{L})$ & 0.06 \\
\hline Density beer going into the sedimenter $\mathrm{kg} / \mathrm{L}$ & 0.98 \\
\hline Flow rate of beer in $\mathrm{L} / \mathrm{h}$ & 1.86 \\
\hline Concentration of the yeast going out $(\mathrm{kg} / \mathrm{L})$ & 0.07 \\
\hline \multicolumn{2}{|l|}{ Distillation } \\
\hline Beer sent to Distilation column $(\mathrm{kg})$ & 1.83 \\
\hline Eletrical power required to distillate one 1 of hydrous Ethanol (MJ) & 0.38 \\
\hline Concentration of alcohol $(\mathrm{kg} / \mathrm{L})$ & $1 \times 10^{-3}$ \\
\hline Density of the beer $(\mathrm{kg} / \mathrm{L})$ & 0.98 \\
\hline Flow rate of the beer to the Sedimentor $(\mathrm{L} / \mathrm{h})$ & 1.86 \\
\hline Purity of Ethanol (\%) in condensate & 0.05 \\
\hline Hydrous Ethanol produced from distillation Column $(\mathrm{kg})$ & $1.96 \times 10^{-3}$ \\
\hline Electrical power required in $\mathrm{MJ}$ & $7.48 \times 10^{-4}$ \\
\hline Thermal power required in $\mathrm{MJ}$ & 0.014 \\
\hline Duration of the batch fermentation (h) & 6 \\
\hline Duration of stripping process $(\mathrm{h})$ & 1 \\
\hline Thermal power required to distilate on litre of hydrous Ethanol (MJ) & 7.16 \\
\hline Stillage $(\mathrm{kg})$ & 1.82 \\
\hline \multicolumn{2}{|l|}{ Yeast-tank } \\
\hline Energy used to keep yeast solution homogeneous (kWh) & $5 \times 10^{-6}$ \\
\hline Duration of batch fermentation (h) & 6 \\
\hline Yeast supplied in the process without recycling $(\mathrm{kg} / \mathrm{h})$ & $5 \times 10^{-3}$ \\
\hline Mass of yeast supplied $(\mathrm{kg} / \mathrm{h})$ & $5 \times 10^{-3}$ \\
\hline \multicolumn{2}{|l|}{ Molecular sieve } \\
\hline Concentration of ethanol in the beer $(\mathrm{kg} / \mathrm{L})$ & 1 \\
\hline Density of the beer $(\mathrm{kg} / \mathrm{L})$ & 0.98 \\
\hline Flow rate of the beer $(\mathrm{L} / \mathrm{h})$ & 1.86 \\
\hline Percentage of impurity in the distillate (\%) & 0.05 \\
\hline Final ethanol concentration $(\%)$ & 99.5 \\
\hline
\end{tabular}

Note: * calculated based on experiments by the authors. 


\section{Appendix 2}

Figure A1. Flowchart for denatured ethanol production process using Blenke cascade system generated by GaBi program.

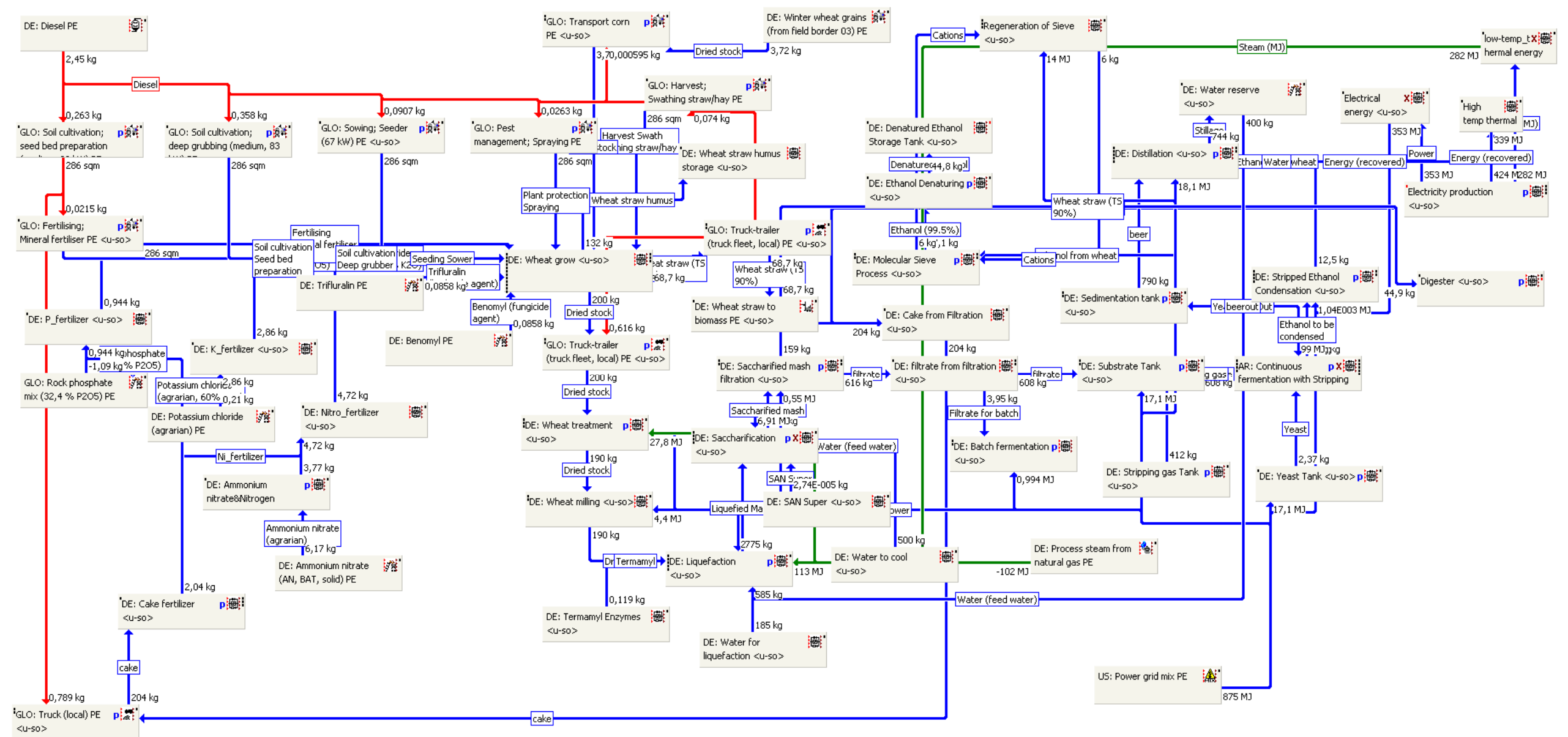

(C) 2013 by the authors; licensee MDPI, Basel, Switzerland. This article is an open access article distributed under the terms and conditions of the Creative Commons Attribution license (http://creativecommons.org/licenses/by/3.0/). 